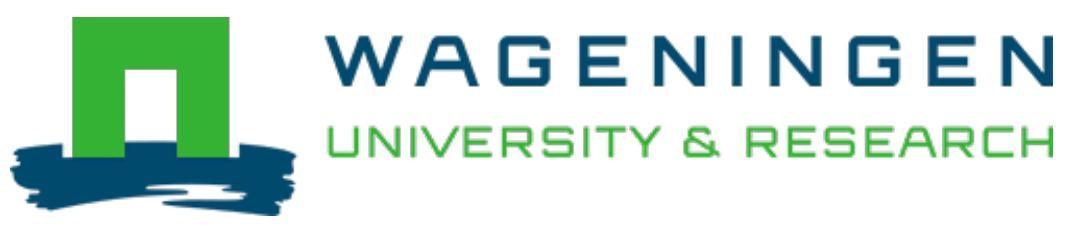

\author{
In vitro solubility of calcium, iron and zinc in relation to phytic acid levels in rice- \\ based consumer products in China \\ International Journal of Food Sciences and Nutrition \\ Liang, J.; Han, B.Z.; Nout, M.J.R.; Hamer, R.J. \\ https://doi.org/10.3109/09637480903229017
}

This publication is made publicly available in the institutional repository of Wageningen University and Research, under the terms of article $25 \mathrm{fa}$ of the Dutch Copyright Act, also known as the Amendment Taverne. This has been done with explicit consent by the author.

Article 25 fa states that the author of a short scientific work funded either wholly or partially by Dutch public funds is entitled to make that work publicly available for no consideration following a reasonable period of time after the work was first published, provided that clear reference is made to the source of the first publication of the work.

This publication is distributed under The Association of Universities in the Netherlands (VSNU) 'Article $25 \mathrm{fa}$ implementation' project. In this project research outputs of researchers employed by Dutch Universities that comply with the legal requirements of Article $25 \mathrm{fa}$ of the Dutch Copyright Act are distributed online and free of cost or other barriers in institutional repositories. Research outputs are distributed six months after their first online publication in the original published version and with proper attribution to the source of the original publication.

You are permitted to download and use the publication for personal purposes. All rights remain with the author(s) and / or copyright owner(s) of this work. Any use of the publication or parts of it other than authorised under article $25 \mathrm{fa}$ of the Dutch Copyright act is prohibited. Wageningen University \& Research and the author(s) of this publication shall not be held responsible or liable for any damages resulting from your (re)use of this publication.

For questions regarding the public availability of this publication please contact openscience.library@wur.nl 


\title{
In vitro solubility of calcium, iron and zinc in relation to phytic acid levels in rice-based consumer products in China
}

\author{
JIANFEN LIANG ${ }^{1,2}$, BEI-ZHONG HAN ${ }^{1}$, M. J. ROBERT NOUT ${ }^{2} \&$ \\ ROBERT J. HAMER ${ }^{2}$ \\ ${ }^{1}$ College of Food Science and Nutritional Engineering, China Agricultural University, Beijing, \\ China, ${ }^{2}$ Department of Agrotechnology and Food Sciences, Wageningen University, Wageningen, \\ The Netherlands
}

\begin{abstract}
In vitro solubility of calcium, iron and zinc in relation to phytic acid (PA) levels in 30 commercial rice-based foods from China was studied. Solubility of minerals and molar ratios of PA to minerals varied with degrees of processing. In primary products, $[\mathrm{PA}] /[\mathrm{Ca}]$ values were less than 5 and $[\mathrm{PA}] /[\mathrm{Fe}]$ and $[\mathrm{PA}] /[\mathrm{Zn}]$ similarly ranged between 5 and 74 , with most values between 20 and 30. [PA]/[mineral] molar ratios in intensively processed products were lower. Solubility of calcium ranged from $0 \%$ to $87 \%$, with the lowest in brown rice $(12 \%)$ and the highest in infant foods $(50 \%)$. Iron solubility in two-thirds of samples was lower than $30 \%$, and that of zinc narrowly ranged from $6 \%$ to $30 \%$. Solubility of minerals was not significantly affected by [PA]/ [mineral]. At present, neither primary nor intensively processed rice-based products are good dietary sources of minerals. Improvements should be attempted by dephytinization, mineral fortification or, preferably, combination of both.
\end{abstract}

Keywords: Calcium, iron, zinc, phytic acid, rice-based food

\section{Introduction}

Rice is a major food cereal in China, and about 95\% of harvested rice is used for consumer food products either as white rice or as processed foods (e.g. noodles) (FAO 2006). Rice serves as the major dietary source of energy, protein, thiamine, riboflavin, niacin, iron and calcium (Juliano 1997; Kennedy et al. 2002). It was reported that in China, during the period 1997-2001, rice products supplied about $30-40 \%$ of the dietary energy intake (Kennedy et al. 2002; FAO 2004). In 2002 the intake of rice and rice products in China was $238 \mathrm{~g} /$ capita/day, which supplied $35 \%$ of the total energy intake (Wang 2005; FAO 2006). This number is even higher in rural areas: estimates from 2002 give an intake of rice and rice products of $246 \mathrm{~g} /$ capita/day.

In China, iron-deficiency-related anaemia is quite common: it affects about $30 \%$ of pregnant and lactating women. This situation did not improve with changes of the dietary structure (increased consumption of legumes and vegetables) aimed at

Correspondence: Jianfen Liang, College of Food Science and Nutritional Engineering, P.O. Box 294, China Agricultural University (East Campers), Haidian District, Beijing 100083, P.R. China. Tel: +86 1062737699. Fax: +86 1062737699 . E-mail: liangjf@cau.edu.cn 
increasing iron intake (Wang 2005). The main reason for iron-deficiency anaemia and mineral malnutrition in China and other predominantly rice-consuming countries is related to the poor bioavailability of iron and other important micronutrients (calcium, zinc). While the Chinese rely on rice and other plant-derived foods for $60 \%$ of their mineral intake, the presence of phytate, a very potent inhibitor of mineral bioavailability, causes a low bioavailability of the minerals concerned (Ma 2007). In order to predict the bioavailability of minerals, molar ratios of phytic acid (PA) to minerals have been used as an indicator (Fordyce et al. 1987; Hira and Kaur 1993; Grewal et al. 1999; Adeyeye et al. 2000; Perlas and Gibson 2002; Ma et al. 2005). Bioavailability levels could also be related to the amount of minerals recovered after in vitro digestion of products with gut enzymes (Larsson et al. 1997; Kiers et al. 2000; Glahn et al. 2002).

$\mathrm{Ma}$ (2007) proposed that iron uptake was inhibited at a molar ratio of $[\mathrm{PA}] /[\mathrm{Fe}]>1$. In earlier studies we reported average values of $[\mathrm{PA}] /[\mathrm{Fe}]$ of 50 in brown rice (predicted bioavailability $<5 \%$ ). Perlas and Gibson mentioned that 15 is the critical value of $[\mathrm{PA}] /[\mathrm{Zn}]$ for zinc bioavailability, and gave changes of these ratios after soaking (Perlas and Gibson 2002). Although information on prediction of the bioavailability of trace elements in unprocessed products becomes increasingly available, information for processed products is still scant. In a previous paper, we demonstrated that especiallywet processing such as fermentation could lead to a substantial reduction in phytate levels (Liang et al. 2007).

According to the extent of processing, primary and intensively processed rice-based products can be distinguished. Primary processed products include brown, white (or polished) and germinated rice and still have the kernel shape. Of these, white rice is the most important consumer product. Although brown rice and germinated rice contain higher levels of nutrients, they are not popular with the public because of their darker colour and unaccepted sensory properties (Huang 2004). Intensively processed products include rice noodles, rice crackers and rice-based infant foods, and mainly originate from further processing of white rice. Whereas several studies addressed process innovations for improved sensory quality (Zhu 1990; Park et al. 2001; Wang et al. 2003; Lu et al. 2005), only one research study included several rice products in a survey of minerals and PA in common Chinese foods (Ma et al. 2005). In previous studies, we reported the natural variation in phytate and mineral levels in Chinese rice (Liang et al. 2007), and the efficacy of dry fractionation and wet processing in improving mineral bioavailability (Liang et al. 2008a, 2008b).

With the present study, we aim to gain understanding of the effect of standard commercial processing on the mineral contents and bioavailability of commercial rice products. To this end, we collected 30 representative rice-based products from commercial outlets in China. All samples were analysed for their contents of minerals and PA. We also assessed the in vitro solubility of minerals after enzymatic digestion. The objectives were: to analyse levels and in vitro solubility calcium, iron and zinc in different rice-based products and their relation to levels of PA; and to evaluate the suitability of rice products as dietary sources of minerals or as carriers for mineral fortification.

\section{Materials and methods}

\section{Sample collection}

Rice-based solid products with a shelf-life longer than 6 months were used for study. Thirty commercial products were selected and purchased at three supermarkets in Beijing. A description of these products is presented in Table I. 


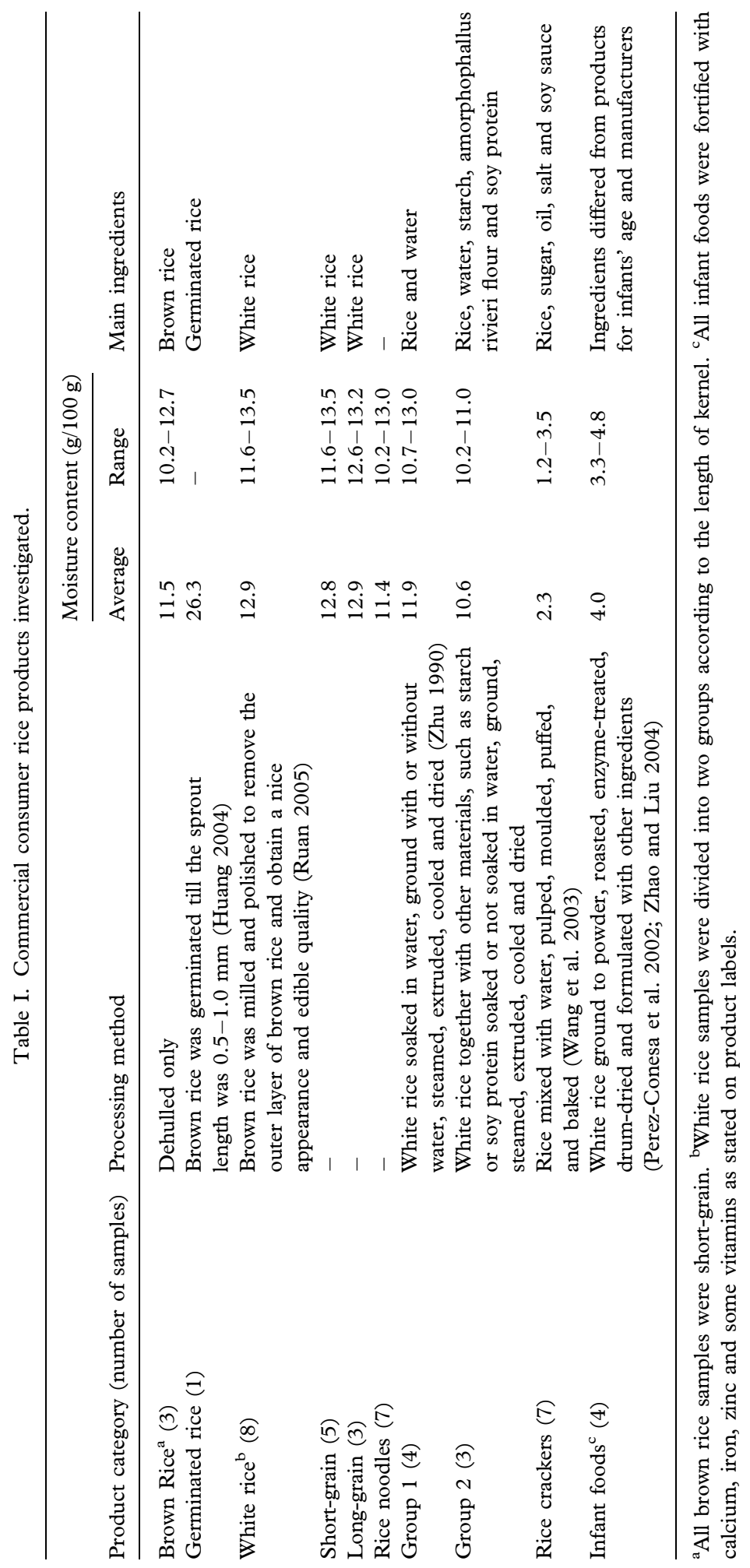


Contents of total and in vitro soluble minerals

For analysis of the total contents of calcium, iron and zinc, $1 \mathrm{~g}$ sample (accuracy $0.0001 \mathrm{~g}$ ) was wet digested with nitric acid (65\%) and perchloric acid (60\%) following the procedure of AOAC 975.03 (Horwitz 2000). In vitro soluble minerals were measured in the supernatant after enzymatic digestion of suspended food samples. Enzymatic digestion followed the procedure of Kiers et al. (2000). After digestion in simulated mouth, stomach and intestine, the reaction mixture was centrifuged at $3,600 \times \mathrm{g}$ at $4^{\circ} \mathrm{C}$ for $15 \mathrm{~min}$ and the supernatants were filtered through a $0.45 \mu \mathrm{m}$ membrane. The calcium, iron and zinc in acid digests and supernatants of enzymatic digests were determined with an inductively coupled plasma optical emission spectrometer (Optima 2000; Perkin-Elmer, Waltham Massachussetts, USA) (Bentsink et al. 2003). During analysis, the sample flow rate was $1.5 \mathrm{ml} / \mathrm{min}$. All samples were digested and analysed in triplicate. In vitro solubility is referred to as the percentage of soluble content to total content of a mineral.

\section{Contents of phytic acid}

PA contents of the product were analysed in triplicate by spectrophotometric detection with ferric chloride and sulphosalicylic acid after extraction, and separation on anion exchange resin, following the procedures described by Ma et al. (2005).

\section{Moisture contents}

Moisture contents in collected samples were analysed following AOAC official method 4.1.09a.

\section{Statistical analysis}

Data were analysed with SPSS 10.0 for windows. Significance was tested at a $5 \%$ level using an independent-samples $t$-test.

\section{Results}

Phytic acid, calcium, iron and zinc, and molar ratios of phytic acid to minerals

PA, calcium, iron and zinc levels of all samples are mapped in Figure 1. In this figure, samples could be clustered into three groups $\mathrm{a}, \mathrm{b}$ and $\mathrm{c}$ as follows.

- Group a: low contents of both phytic acid and minerals. This group had PA levels lower than $3.7 \mathrm{mg} / \mathrm{g}$ (wet weight), and calcium, iron and zinc levels below $66 \mathrm{mg} / 100 \mathrm{~g}$, $3.1 \mathrm{mg} / 100 \mathrm{~g}$ and $1.9 \mathrm{mg} / 100 \mathrm{~g}$, respectively. Twenty-two samples, including all white rice samples, rice noodles and rice crackers, can be found in this group. Contents of calcium were in the range $2-66 \mathrm{mg} / 100 \mathrm{~g}$. They were lower than $20 \mathrm{mg} /$ $100 \mathrm{~g}$ in 16 samples and ranged from 22 to $66 \mathrm{mg} / 100 \mathrm{~g}$ for the other six samples. Sixteen samples had contents of iron in the range $0.6-1.5 \mathrm{mg} / 100 \mathrm{~g}$, and the other six contained $1.5-3.1 \mathrm{mg} / 100 \mathrm{~g}$. Eighteen samples had contents of zinc ranging from 0.8 to $1.6 \mathrm{mg} / 100 \mathrm{~g}$, three in the range $1.7-2.0 \mathrm{mg} / 100 \mathrm{~g}$, and one lower than $0.6 \mathrm{mg} / 100 \mathrm{~g}$.

- Group b: low contents of phytic acid and high levels of minerals. This group consisted of four infant foods. Samples in this group had similar levels of minerals, which were 


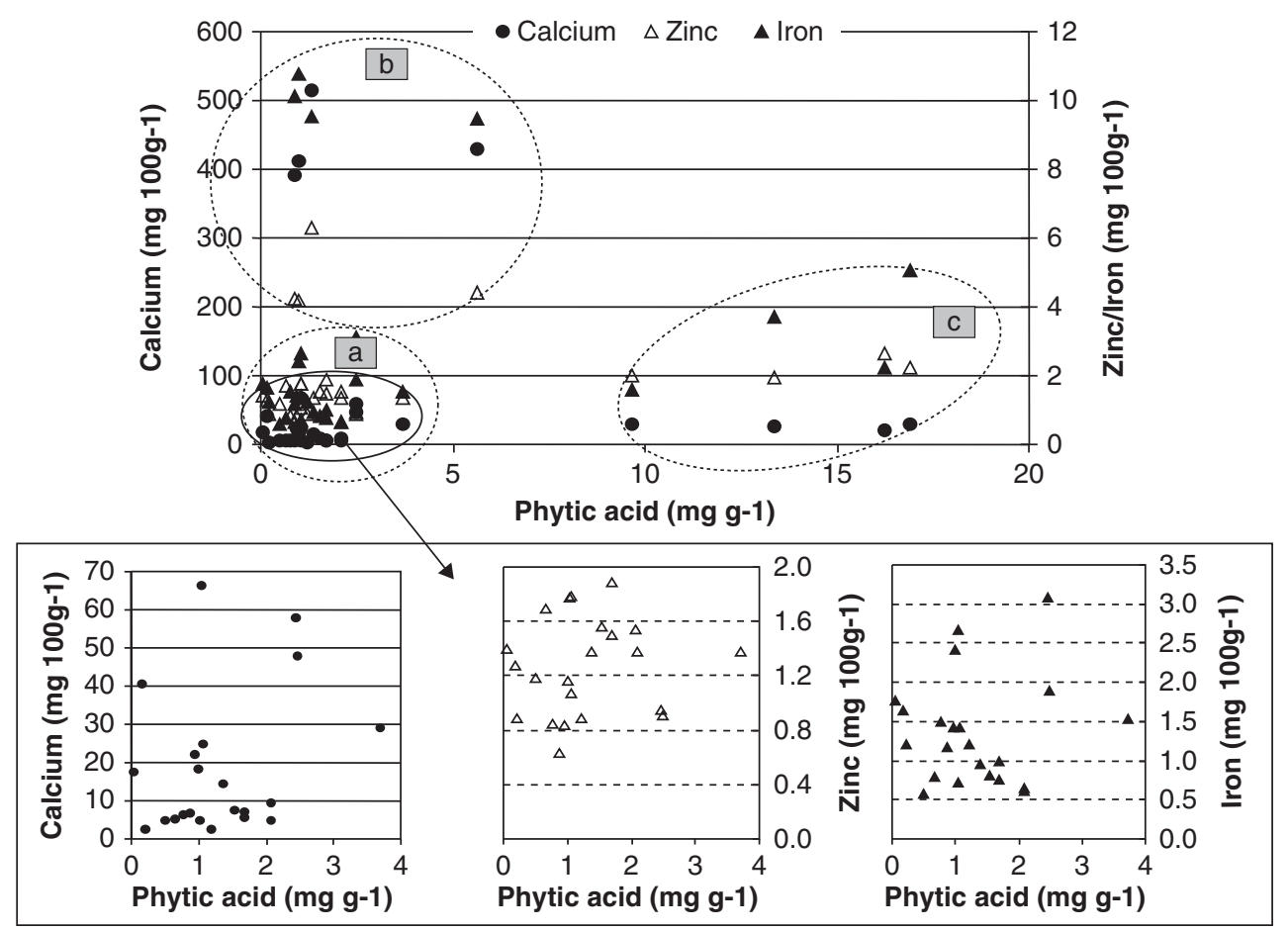

Figure 1. Levels of PA and minerals (calcium, iron and zinc) in consumer rice products. Each sample was in one of the three groups: (a) white rice-based products; (b) brown rice-based products; (c) mineral-fortified products. Bottom: For better comparison, contents of PA and minerals in most of the white rice-based products are presented.

about $450 \mathrm{mg} / 100 \mathrm{~g}, 10 \mathrm{mg} / 100 \mathrm{~g}$ and $4 \mathrm{mg} / 100 \mathrm{~g}$ for calcium, iron and zinc, respectively, due to mineral fortification, and different levels of PA $(0.9-5.9 \mathrm{mg} / \mathrm{g})$ resulting from different pre-treated ingredients. Consumption of $50 \mathrm{~g}$ food from this group would result in about $200-260 \mathrm{mg}$ calcium intake, $5 \mathrm{mg}$ iron and 2-3 mg zinc, but at the same time 50-300 $\mathrm{mg}$ of PA would be intake.

- Group c: high contents of phytic acid and low levels of minerals. This group represents brown and germinated rice. Levels of calcium, iron and zinc were $20-40 \mathrm{mg} / 100$ g, $2-6 \mathrm{mg} / 100 \mathrm{~g}$ and $2-3 \mathrm{mg} / 100 \mathrm{~g}$, respectively, and PA levels were $10-17 \mathrm{mg} / \mathrm{g}$. Consumption of rice products from this group will result in higher mineral intake; however, a considerable intake of PA will take place at the same time.

Table II presents the levels of PA, calcium, iron and zinc and the molar ratios of PA to minerals in the various product categories. Compared with the other categories, infant foods had higher levels of minerals $(\mathrm{P}<0.01)$. Among the other five categories, the highest levels of calcium and zinc occurred in germinated rice, and the highest levels of PA and iron occurred in brown rice. PA in brown rice was significantly higher than in groups of white rice and products originated from white rice $(P<0.01)$. However, PA in noodles, crackers and infant foods was not significantly different $(P>0.05)$. White rice had the lowest contents of calcium and iron $(P<0.05)$. Noodles and crackers had similar mineral levels. PA levels in noodles and crackers were similar to those of white rice, about $10 \%$ of brown rice. This indicated that milling brown to 


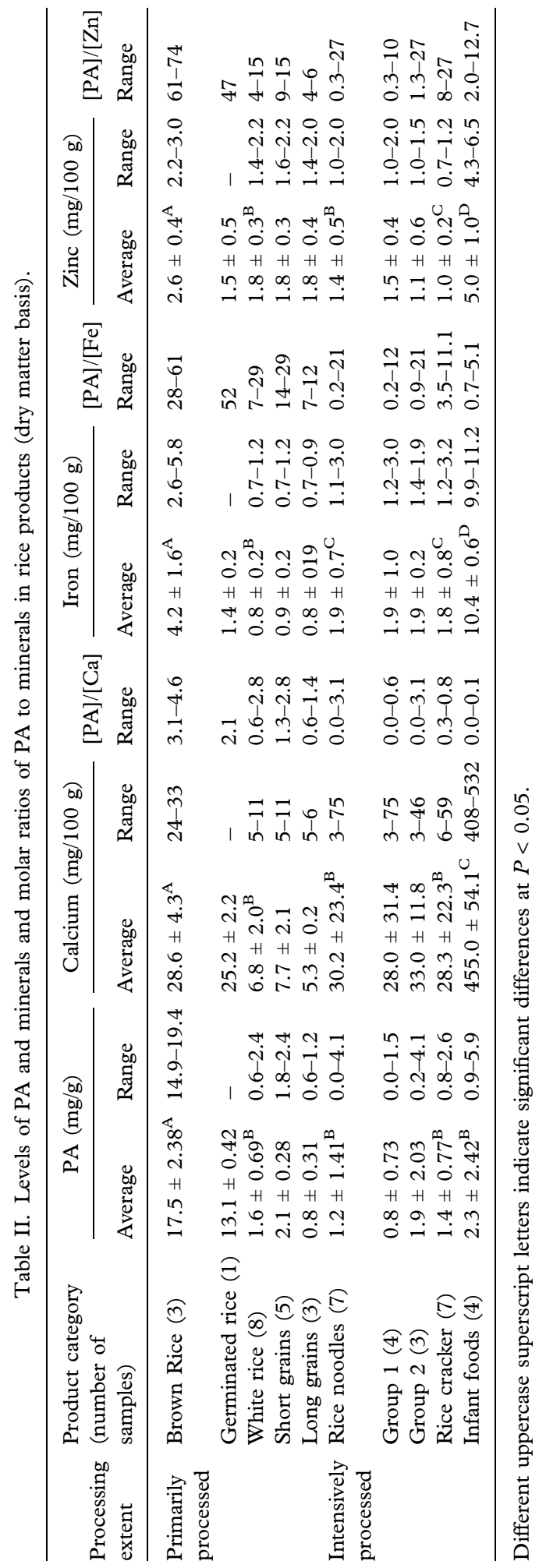


white rice significantly reduced PA levels, but that further processing, involving soaking, fermentation and enzymatic treatment, did not significantly affect PA.

As shown in Table II, the molar ratios of PA to minerals were different for the respective types of minerals and rice products. In all product categories, $[\mathrm{PA}] /[\mathrm{Ca}]$ ratios ranged between 0.0 and 4.6. This was much lower and the range was narrower than for $[\mathrm{PA}] /[\mathrm{Fe}](0.2-61)$ and $[\mathrm{PA}] /[\mathrm{Zn}](0.3-74)$. Ratios of $[\mathrm{PA}] /[\mathrm{Ca}],[\mathrm{PA}] /[\mathrm{Fe}]$ and $[\mathrm{PA}] /[\mathrm{Zn}]$ in brown rice and germinated rice were much higher than in other products. Infant foods had the lowest ratio of $[\mathrm{PA}] /[\mathrm{Ca}]$, probably due to the calcium added. In the category of noodles, the largest variation of PA to minerals ratio was observed. These variations result from diverse contents of PA and/or minerals.

\section{In vitro solubility of calcium, iron and zinc in rice products}

The phytate to mineral ratio provides a crude indicator for mineral bioavailability. The amount of minerals solubilized after in vitro digestion of a sample is closer to the in vivo situation and may therefore be more predictive for true bioavailability.

As shown in Table III, the in vitro solubility of minerals differed among the product categories. The solubility of calcium ranged between $0 \%$ and $87 \%$, with the lowest average $(12 \%)$ in brown rice and the highest $(50 \%)$ in infant foods. Iron and zinc solubility ranged between $0 \%$ and $83 \%$ and between $0 \%$ and $34 \%$, respectively. Both white rice and brown rice categories showed the highest average solubility of iron and zinc. In both primary and intensively processed products, the average solubility of calcium and iron was much higher than in brown rice. In contrast, germination as well as intensive processing (noodles and crackers) led to a decreased solubility of zinc.

Figures 2 and 3 show the in vitro solubility of calcium, and of iron and zinc, respectively, in relation to the $[\mathrm{PA}] /[$ mineral $]$ ratios for each of the samples analysed. Calcium solubility varied in a wide range from $<1 \%$ to $>80 \%$ when the $[\mathrm{PA}] /[$ mineral] ratios were lower than 1 . Beyond a ratio of 1 , most products had a calcium solubility of around $20 \%$. A similar phenomenon was observed in model studies. The iron solubility in about two-thirds of the products was lower than $30 \%$, and that of zinc had a narrow range between $6 \%$ and $30 \%$. The solubility of iron and zinc was not significantly affected by molar ratios of PA to minerals. Figures 2 and 3 indicate that mineral solubility is not exclusively determined by the molar ratio $[\mathrm{PA}] /[\mathrm{Fe}]$, but that other

Table III. In vitro solubility (\% of total content) of calcium, iron and zinc in rice products.

\begin{tabular}{|c|c|c|c|c|c|c|}
\hline \multirow{2}{*}{$\begin{array}{l}\text { Product category } \\
\text { (number of samples) }\end{array}$} & \multicolumn{2}{|c|}{ Calcium } & \multicolumn{2}{|c|}{ Iron } & \multicolumn{2}{|c|}{ Zinc } \\
\hline & Average & Range & Average & Range & Average & Range \\
\hline Brown Rice (3) & $12.0 \pm 5.6^{\mathrm{A}}$ & $5.6-15.4$ & $15.7 \pm 9.2^{\mathrm{A}}$ & $5.2-22.5$ & $19.6 \pm 5.1^{\mathrm{A}}$ & $15.8-25.4$ \\
\hline Germinated rice $(1)$ & $18.0 \pm 12.1$ & - & $38.6 \pm 29.5$ & - & $18.9 \pm 6.7$ & - \\
\hline White rice (8) & $16.2 \pm 14.8^{\mathrm{A}}$ & $0.0-29.7$ & $50.2 \pm 27.7^{\mathrm{A}}$ & $0.0-82.8$ & $17.8 \pm 3.8^{\mathrm{A}}$ & $13.5-33.5$ \\
\hline Short-grain (4) & $21.1 \pm 7.1$ & $0.0-29.7$ & $19.1 \pm 24.5$ & $7.0-82.8$ & $20.7 \pm 11.0$ & $13.5-22.7$ \\
\hline Long-grain (4) & $42.2 \pm 18.3$ & $15.8-29.2$ & $23.2 \pm 14.9$ & $0.0-46.7$ & $4.9 \pm 4.7$ & $14.2-33.5$ \\
\hline Rice noodles (7) & $45.6 \pm 23.8^{\mathrm{B}}$ & $28.6-80.4$ & $24.5 \pm 10.9^{\mathrm{A}}$ & $0.0-44.0$ & $3.1 \pm 2.1^{\mathrm{B}}$ & $1.0-14.4$ \\
\hline Group 1 (4) & $33.7 \pm 10.5$ & $29.0-80.4$ & $21.2 \pm 22.0$ & $14.8-38.9$ & $7.2 \pm 6.7$ & $1.1-5.5$ \\
\hline Group 2 (3) & $38.2 \pm 6.3$ & $28.6-49.1$ & $24.5 \pm 0.3$ & $0.0-44.0$ & $11.8 \pm 3.4$ & $1.0-14.4$ \\
\hline Rice crackers (7) & $29.1 \pm 17.8^{\mathrm{A}}$ & $3.4-49.4$ & $31.7 \pm 23.4^{\mathrm{A}}$ & $0.0-69.7$ & $10.7 \pm 9.4^{\mathrm{B}}$ & $0.0-26.6$ \\
\hline Infant foods (4) & $50.2 \pm 31.3^{\mathrm{A}}$ & $15.9-86.8$ & $9.6 \pm 8.6^{\mathrm{A}}$ & $1.4-19.8$ & $13.8 \pm 11.0^{\mathrm{A}}$ & $6.1-30.1$ \\
\hline
\end{tabular}

Different uppercase superscript letters indicate significant differences at $P<0.05$. 


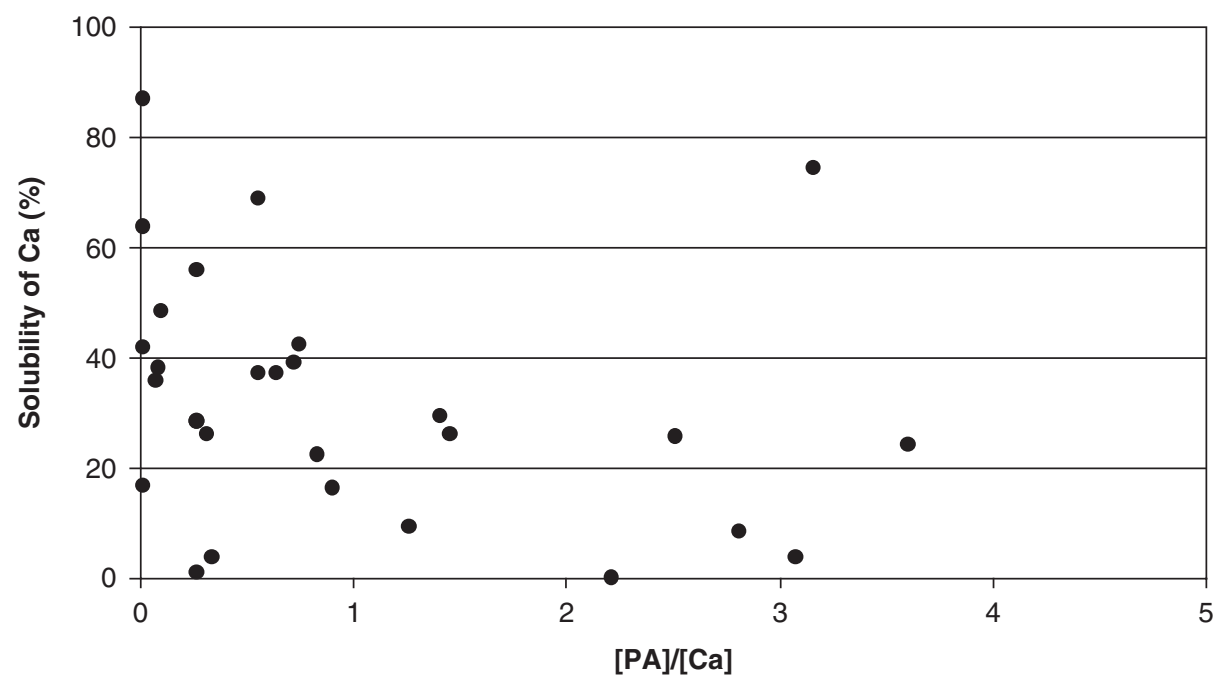

Figure 2. In vitro solubility of calcium in consumer rice products.

factors also play a role. Such factors may include added fortificants and the presence of food matrix components such as dietary fibre and free phosphate.

\section{Discussion}

According to the Chinese Dietary Reference Intake for adults, the adequate intake of iron is $15-20 \mathrm{mg}$ /day and of calcium is $800 \mathrm{mg} /$ day, and the Dietary Reference Intake of zinc is $15-20 \mathrm{mg} /$ day (Chinese Nutrition Society 2000). When calculated on the basis of the per-capita consumption of rice and rice products of $238 \mathrm{~g} /$ day (Wang 2005)

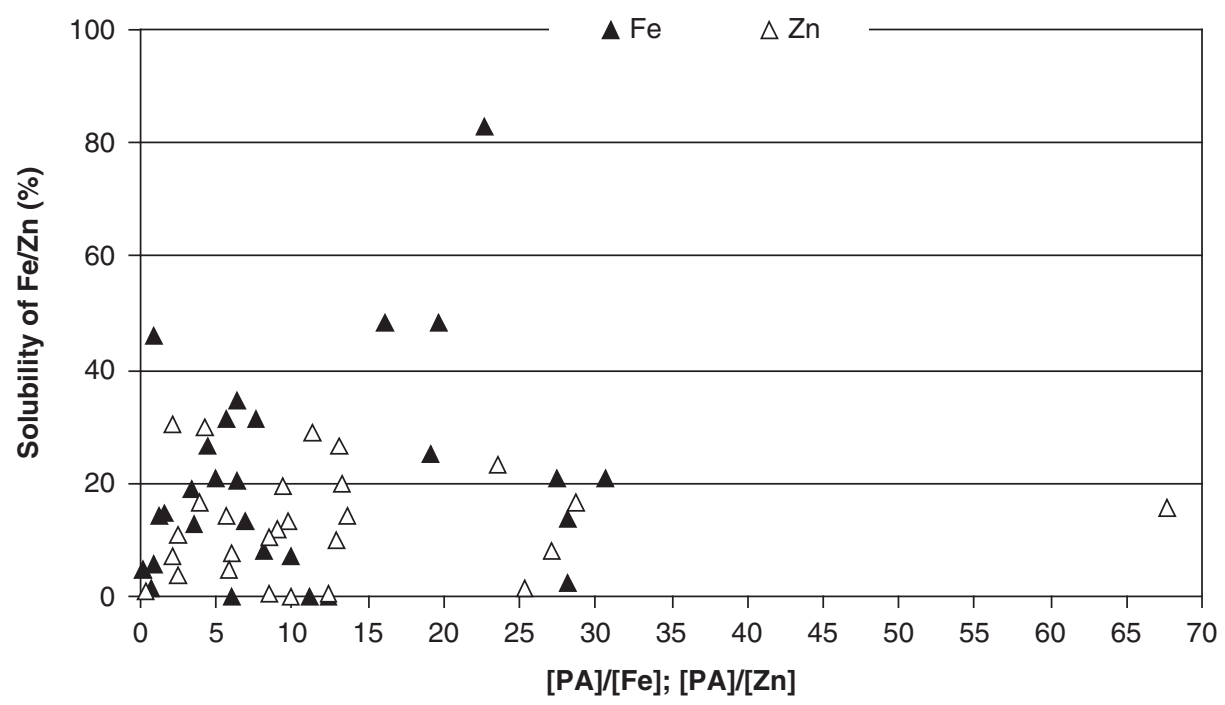

Figure 3. In vitro solubility of iron and zinc in consumer rice products. 
and the average contents of minerals found in the present study, rice-based products supply $6 \%$ of the calcium adequate intake, $25 \%$ of the iron adequate intake, and $26 \%$ of the Dietary Reference Intake for zinc.

Primary processed rice products cannot be considered good sources of minerals for several reasons. First, the solubility (as an index for bioavailability) of calcium and iron was very low in brown rice because of a high level of PA. Milling and polishing achieves $90 \%$ removal of PA, thus increasing the minerals' solubility. However, the levels of calcium and iron are also reduced significantly $(70-80 \%)$ by primary processing. With respect to calcium and iron, germination is a good way to improve their solubility (bioavailability), since both the levels as well as the solubility of calcium and iron increased after germination. Enzymatic degradation of PA and other components chelated to minerals during steeping and germination of brown rice contributed to the increase of solubility. On the other hand, for all primary products, white rice is the most important staple food, while brown rice-a good source of zinc-and germinated rice are not widely consumed because their sensory properties are not appreciated by most Chinese consumers (Huang 2004).

Intensively processed rice products are popular with various groups of Chinese consumers, so they also have an impact on the human mineral status. Rice noodles are used as staple foods, especially in Southern China (Lu et al. 2005). Significant higher solubility of calcium and zinc than other products and the nature of the noodle-making process make noodles a good source and an attractive vehicle to enhance intake of minerals. During noodle-making, rice is soaked and fermented during periods ranging from several hours to 3 days, prior to noodle-making. During these preliminary phases, endogenous rice phytase as well as microbial phytases produced by fermentation microbiota reportedly degrade PA (Umeta et al. 2005), which may explain the low levels of PA observed in rice noodles. Differences in noodle-making procedures result in variations of product composition (Marfo et al. 1990). Like PA, the levels of minerals in rice noodles are also determined by processing procedures and/or the use of ingredients and equipment. For calcium, the lowest value was caused mainly by the loss of calcium by leaching effects, while the highest levels are probably due to the application of calcium-rich additives. Concerning iron, all noodles had higher iron levels than white rice. We suppose this is related to low $\mathrm{pH}$ values occurring during noodle processing and the use of cast-iron processing machines. Neither equipment nor ingredients affected zinc, the levels of which are similar to those in white rice. Crackers are mainly consumed in small quantities as a snack, and thus will not greatly affect the mineral status. Compared with other products, the infant foods are more important - since they constitute an almost exclusive dietary source of macronutrients and micronutrients, and because they are consumed in relatively small quantities (Lind et al. 2003). Mineral solubility in, for example, infant foods can be improved by various strategies. Enzymatic pre-treatment of white rice (e.g. with phytase) will significantly improve mineral solubility, as was shown elsewhere with soya bean formulas (Davidsson 2003).

Data presented here show an inverse relation between PA levels and the solubility of calcium and zinc. The inadequate solubility of iron in some infant foods tested might be due to the use of an ineffective chemical form of iron used for fortification (Engle-Stone et al. 2005). In addition, interaction of minerals also affects the solubility of calcium, iron and zinc (Fordyce et al. 1987). However, some studies mentioned that even the combination of favourable factors such as reduction of PA, sufficient 
fortification of iron and addition of ascorbic acid (an enhancer of iron absorption) did not clearly improve iron and zinc status in infant foods (Lind et al. 2003; Mamiro et al. 2004; Lachat et al. 2006). This suggests that other inhibitory factors, such as dietary fibre and the product matrix, may interfere with mineral uptake. Therefore, the ultimate test remains the in vivo measure of uptake.

Promising approaches for the enhancement of bioavailability of minerals in rice products are to increase mineral levels by supplementation or fortification, to increase bioavailability through added enhancers or by removal of inhibitors (Gibson et al. 2000; Davidsson 2003), or combinations thereof. Considering the variability of iron and zinc levels in rice varieties from growing regions in China (Graham et al. 1999; Liang et al. 2007), there is a potential in selecting crops with maximum mineral and minimum PA levels. The specific localization of minerals and PA also enable an optimized milling procedure resulting in maximum retention of minerals and removal of PA (Liang et al. 2008b). This would contribute to improved bioavailability of particularly iron, zinc and calcium (Engle-Stone et al. 2005). Fortification with minerals should take into account their interactions, palatability (especially for iron compounds), and opportunities for enhancement by ascorbic acid-rich fruit and vegetables (Kennedy et al. 2002; Davidsson 2003; Engle-Stone et al. 2005).

\section{Conclusions}

The diversity of products and processing methods for rice offers opportunities for improvement of mineral bioavailability in rice-consuming regions. From the presented results of contents and solubility of minerals, it was found that primary processed rice products are poor sources of minerals, either because of low bioavailability or because of their low consumer acceptance. Some intensively processed products (except infant foods; e.g. rice noodles) could improve mineral nutrition via the approaches of the use of materials (ingredients) and application of processing methods. Some infant foods need further processing to decrease their levels of PA or other inhibitors, thus increasing mineral bioavailability.

\section{Acknowledgements}

Financial support was provided by Wageningen University through the North-South Interdisciplinary Research and Education Fund (INREF). The authors gratefully acknowledge the assistance of $\mathrm{Lin} \mathrm{Li}$ and Jin Ying for mineral analysis.

\section{References}

Adeyeye EI, Arogandade LA, Akintayo ET, Aisida OA, Alao PA. 2000. Calcium, zinc and phytate interrelationships in some foods of major consumption in Nigeria. Food Chem 71:435-441.

Bentsink L, Yuan K, Koornneef M, Vreugdenhil D. 2003. The genetics of phytate and phosphate accumulation in seeds and leaves of Arabidopsis thaliana, using natural variation. Theor Appl Genet 106:1234-1243.

Chinese Nutrition Society. 2000. Chinese DRIs [in Chinese]. Beijing: China Light Industry Press. pp 144-189.

Davidsson L. 2003. Approaches to improve iron bioavailability from complementary foods. J Nutr 133:1560S-1562S.

Engle-Stone R, Yeung A, Welch R, Glahn R. 2005. Meat and ascorbic acid can promote Fe availability from $\mathrm{Fe}$-phytate but not $\mathrm{Fe}$-tannic acid complexes. J Agric Food Chem 53:10276-10284. 
FAO. 2004. The state of food insecurity in the world, rice and food security. Rome: FAO.

FAO. 2006. FAOstat. Available online at: http://faostat.fao.org/ (accessed November 2008).

Fordyce EJ, Forbes RM, Robbins KR, Erdman JW. 1987. Phytate x calcium/zinc molar ratios: Are they predictive of zinc bioavailability? J Food Sci 52:440-444.

Gibson RS, Hotz C, Temple C, Yeudall F, Mtitimuni B, Ferguson E. 2000. Dietary strategies to combat deficiencies of iron, zinc, and vitamin A in developing countries: Development, implementation, monitoring, and evaluation. Food Nutr Bull 21:219-231.

Glahn RP, Wortley GM, South PK, Miller DD. 2002. Inhibition of iron uptake by phytic acid, tannic acid, and $\mathrm{ZnCl}_{2}$ : Studies using an in vitro digestion/Caco-2 cell model. J Agric Food Chem 50:390-395.

Graham R, Senadhira D, Beebe S, Iglesias C, Monasterio I. 1999. Breeding for micronutrient density in edible portion of staple food crops: conventional approaches. Field Crops Res 60:57-80.

Grewal HK, Hira CK, Kawatra BL. 1999. Zinc, calcium and iron availability using molar ratios in processed and cooked wheat products. J Food Sci Technol 36:453-456.

Hira CK, Kaur AP. 1993. Phytate/zinc and phytate x calcium/zinc ratios of common cereals, legumes and their combinations. J Food Sci Technol 30:213-215.

Horwitz W. 2000. Official methods of analysis of AOAC International. Association of Official Analytical Chemists. Washington, DC: AOAC International.

Huang SE. 2004. The bright market prospects of functional germinated brown rice [in Chinese]. Food Mach 20:50-51.

Juliano BO. 1997. Rice products in Asia. Laguna, Philippines: Regional Office for Asia and the Pacific. pp $1-42$.

Kennedy G, Burlingame B, Nguyen N. 2002. Nutritional contribution of rice and impact of biotechnology and biodiversity in rice-consuming countries. In: Proceedings of the 20th session of the international rice commission. Bangkok: FAO. pp 59-69.

Kiers LJ, Nout MJR, Rombouts FM. 2000. In vitro digestibility of processed and fermented soya bean, cowpea and maize. J Sci Food Agric 80:1325-1331.

Lachat CK, Van Camp JH, Mamiro PS, Wayua FO, Opsomer AS, Roberfroid DA, Kolsteren PW. 2006. Processing of complementary food dose not increase hair zinc level and growth of infants in Kilosa district, rural Tanzania. Br J Nutr 95:174-180.

Larsson M, Minekus M, Havenaar R. 1997. Estimation of the bioavailability of iron and phosphorus in cereals using a dynamic In vitro gastrointestinal model. J Sci Food Agric 74:99-106.

Liang J, Han BZ, Han L, Nout MJR, Hamer RJ, 2007. Iron, zinc, and phytic acid content of selected rice varieties from China. J Sci Food Agric 87:504-510.

Liang J, Han BZ, Nout MJR, Hamer RJ. 2008a. Effect of soaking, germination and fermentation on phytic acid, total and in vitro soluble zinc in brown rice. Food Chem 110:821-828.

Liang J, Li Z, Tsuji K, Nakano K, Nout MJR, Hamer RJ, 2008b. Milling characteristics and distribution of phytic acid and zinc in long-, medium- and short-grain rice. J Cereal Sci 48:83-91.

Lind T, Lonnerdal B, Persson LA, Stenlund H, Tennefors C, Hernell O. 2003. Effect of weaning cereals with different phytate contents on hemoglobin, iron stores, and serum zinc: A randomized intervention in infants from 6 to 12 months of age. Am J Clin Nutr 78:168-175.

Lu ZH, Li LT, Min WH, Wang F, Tatsumi E. 2005. The effect of natural fermentation on the physical properties of rice flour and the rheological characteristics of rice noodles. Int J Food Sci Technol 40:985-992.

Ma G. 2007. Iron and zinc deficiencies in China: Existing problems and possible solutions. Dissertation, Wageningen University, The Netherlands.

Ma G, Jin Y, Piao J, Kok F, Bonnema G, Jacobsen E. 2005. Phytate, calcium, iron, and zinc contents and their molar ratios in food commonly consumed in China. J Agric Food Chem 53:10285-10290.

Mamiro PS, Kolsteren PW, van Camp JH, Roberfroid DA, Tatala S, Opsomer AS. 2004. Processed complementary food does not improve growth or hemoglobin status of rural Tanzanian infants from 6-12 months of age in Kilosa district, Tanzania. J Nutr 134:1084-1090.

Marfo EK, Simpson BK, Idowu JS, Oke OL. 1990. Effect of local food processing on phytate levels in cassava, cocoyam, yam, maize, sorghum, rice, cowpea, and soybean. J Agric Food Chem 38:1580-1585.

Park JK, Kim SS, Kim KO. 2001. Effect of milling ratio on sensory properties of cooked rice and on physicochemical properties of milled and cooked rice. Cereal Chem 78:151-156.

Perez-Conesa D, Ros G, Periago MJ. 2002. Protein nutritional quality of infant cereals during processing. J Cereal Sci 36:125-133.

Perlas LA, Gibson RS. 2002. Use of soaking to enhance the bioavailability of iron and zinc from rice-based complementary foods used in the Philippines. J Sci Food Agric 82:1115-1121. 
Ruan S. 2005. Technology of good quality rice production [in Chinese]. Cereal Feed Industry 12:13-16. Umeta M, West CE, Fufa H. 2005. Content of zinc, iron, calcium and their absorption inhibitors in foods commonly consumed in Ethiopia. J Food Comp Anal 18:803-817.

Wang L. 2005. 2002 China nutrition and health survey [in Chinese]. People's Medical Publishing House. Wang Z, Zhao S, Xiong S, Jiang S. 2003. Study on the processing of extruded rice cake [in Chinese]. J Cereals Oils 17:5-7.

Zhao S, Liu X. 2004. Study on nutritional rice powder for infants [in Chinese]. Shandong Food Sci Technol 14:27-29.

Zhu R. 1990. Introduction of rice noodle [in Chinese]. Cereal Feed Industry 12:13-15. 